\title{
2 Social Institutions and the Quality of Democracy
}

Democracy as a form of government comes in many forms. Even though supported by most citizens in democratic states, what they cherish are widely different systems. This plurality is crucial when the quality of democratic governance is to be evaluated; it is not a given what the ambitions of a specific system are to be measured against, and accordingly what the relevant variables to be assessed are. However, variation not only concerns strictly political systems as such but also the relationship between political institutions and the social institutions that are not directly part of political processes. Specifying how social institutions constitute a part of democracy is the aim of this chapter.

Despite the plurality of democratic forms the present discussion does not take a systematic comparative approach but rather concentrates on the model of democracy common to the Nordic countries, with most empirical specifications taken from the Norwegian context. This does not imply that these societies are exemplary but rather that they represent a special case of well-established democratic governance with a long history of continuous political reformism. The analysis is based on the presumption that in the absence of a comparative study, a strategic study of one case may throw light on other, different cases as well.

The chapter concentrates on two properties of Nordic democracy, its institutional and normative aspects. Nordic democracy is discussed by Aakvaag (this volume) with mostly non-normative perspectives on the institutional preconditions for individual freedom, whereas the present chapter sets its focus on democratic norms and the space for democratic deliberation within social institutions. Three basic institutions are surveyed: economy/working life, the welfare state and the media; together they constitute the main components of the general version of the Nordic model (Engelstad, Larsen, \& Rogstad, 2017).

By contrast, two prominent contributions within what may be termed the mainstream model of the quality of democracy serve as a starting point. The first is the set of criteria listed by Robert Dahl in Democracy and Its Critics (1989, pp. 108ff.): effective participation, voting equality, enlightened understanding and control of agenda constitute the ideal elements of citizens' equal political opportunities. Despite their obvious value, these criteria are limited in two respects: they concern only political institutions and only implicitly take into account the functioning of these institutions. Recently, Larry Diamond made a salient contribution to the assessment of democracy with In Search of Democracy (2016), with broader and more precise measurements. By synthesizing three well-established measurements of democracy under the headings of political and electoral rights, civil liberties, rule of law and the functioning of government, Diamond and co-workers distil 19 sub-criteria (Diamond, Green, \& Galley, 2016, p. 65). Here, a clear focus is set on the functioning of political 
institutions, something that represents a step forward compared to Dahl's broad criteria of participation. At the same time, the sphere of political institutions is not transcended, a limitation that follows from the broad comparative perspectives that are Diamond's hallmark. But it comes at some cost. One is that crucial variations within the well-established democracies in the Western hemisphere are overlooked. Another is that the interplay of democracy and 'non-political' social institutions remains unnoticed.

The present chapter follows a different track in order to explore additional elements in what constitutes a good democracy. The quality as well as the stability of democratic governance is integrated in the large set of social institutions indirectly related to politics. That political institutions in a narrow sense are complemented by voluntary organizations and social movements is commonplace and also described by Diamond (2016, pp. 118ff.). But other social fields, permanently present in the life of citizens, such as education, health care and others, may be equally important to the quality of democracy. Even if shaped by democratic processes, they in turn give input to and shape the functioning of democracy. Hence, the quality of democracy refers both to the functioning of political institutions and to the extension of democratic ideals to other social institutions. This broader view on democracy raises two questions: (i) Does it make sense to introduce democratic concepts to institutions outside of politics? And, if so, (ii) how does this affect the quality of democracy in general? In other words, the question is not only what constitutes a democratic state but also what a democratic society can be.

These issues may be seen as a reformulation of discussions of participatory democracy from the late 1960s on. A prominent contribution was Carole Pateman's Participation and Democratic Theory (1970). Drawing a parallel to James Stuart Mill's point that participation in local democracy should be seen as a preparation for national politics, Pateman argued that participation in decision-making in working life serves to widen the democratic process. The gapin Pateman's argumentation, however, was the absence of reflection on institutional specificities and requirements and thereby on the relationship between politics and working life - that is, what kinds of complementarities and incompatibilities exist between the two social spheres.

Jeffrey Alexander's The Civil Sphere (2006) is a more recent effort to broaden the conception of democracy by 'bringing democracy back in' (p. 37). Alexander singles out the civil sphere as a particular institution consisting of mass media, opinion polls and some but not all voluntary organizations (2006, Ch. 5). The civil sphere (overlapping with but not identical to the public sphere as conceived by Habermas 1989) is the arena for solidarity and inclusion, operating via language and social meaning. The specific norm linking to democracy is universality, as a potential force albeit never fully realized in practice (2006, pp. 48ff.). However, Alexander's broadened conception of democracy is limited to the civil sphere; other institutional fields are analyzed as its boundary conditions but not as potentially democratic in their own right. 


\subsection{The Salience of Normative Theory}

To grasp the continuity of democracy and social institutions it is necessary to focus on normative aspects, the norms embodied in democratic processes as well as in social institutions. Even though institutions are practical regulations, they cannot be reduced to purely pragmatic concerns, as assumed by the theory of rational action (North, 1990; Hall \& Taylor, 1996). Without normative justification institutions would hardly be viable. Simultaneously, norms remain abstract if they are not connected to practical arrangements and adapted to the empirical features of institutions. Yet, the significance of democratic norms and processes within social institutions has received insufficient attention. However, two prolific political philosophers, John Rawls and Michael Walzer, are noteworthy exceptions. Despite their different approaches, both emphasize the salience of social institutions to a just society - in other words, to democratic society at its best.

In Theory of Justice (1971) John Rawls elaborated his conception of justice within constitutional, liberal democracy (1971, p. 222). These ideas were further developed in Political Liberalism (1993) and The Idea of Public Reason Revisited (1997), with greater emphasis on legitimacy. In addition to the democratic mechanisms of decision-making used by politicians and voters, Rawls emphasized the norms that induce citizens to social cooperation and reciprocity as an essential part of democracy (1993, pp. 15ff). His main focus is not on individual welfare, but on the political conception of the person as citizen (1993, p. 29,1997, p. 800) and the abilities of individuals within society's institutions. The autonomous individual enjoys rights that guarantee participation in society, and thus is able to take responsibility for his or her own choices. Here, autonomy may be taken in its Kantian meaning: freedom to formulate one's own law on the condition that it is generalizable to society as a whole (Rawls 1971, p. 251). However, autonomy is later specified as a political, not an ethical value (1993, pp. 77, 99).

Given that no society can realize full substantive equality, social inequalities are balanced by two principles. (i) The principle of liberty prescribes that citizens have an equal right to a fully adequate scheme of equal basic liberties. (ii) The difference principle states that social and economic inequalities are acceptable given that (a) offices and positions are open to all and that (b) the unequal distribution of resources takes a form that is to the greatest benefit of the least advantaged members of society (1993, p. 291).

Institutions are understood by Rawls within the frame of the basic structure of society, consisting of 'the main political, social, and economic institutions, and how they fit together into one unified system of social cooperation from one generation to the next' (1993, p. 11). At the same time, institutions have a multiplicity of specific tasks, which cannot be directly assessed by general principles (1993, p. 261, 1997, p. 789). Thus, the liberty principle and the difference principle constitute a background for the assessment of institutions and their relationship. The social institution most 
commonly mentioned by Rawls is the economy (1971, p. 265ff; 2002, § 41-42), mainly in connection with alternative economic systems, property rights and prospects for economic democracy. The family as a basic institution is also taken up, not least with reference to gender inequalities (1997, p. 787ff, 2002, § 50). Even so, Rawls’ description of institutions remains at a general level, situated as parts of the basic structure.

In the years after $A$ Theory of Justice (1971) Rawls developed and changed his conception of the basic structure, from an idea of a fully integrated society to what he later termed a reasonable pluralist society (1993, p. 36), resting on the assumption that conflicts between religious and ideological strands are inevitable. '[T]he idea of a well-ordered society of justice as fairness is unrealistic ... because it is inconsistent with realizing its own principles under the best foreseeable conditions' (1993, p. xvii). Two conclusions follow from this acknowledgement: first, that the basic structure of society is dependent on an overlapping consensus to secure the acceptance and accommodation of these conflicts (1993, pp. 144ff.), in the light of public reason $(1993,1997)$. This means that the heuristic device of 'the original position' from which Rawls derived his conception of justice as fairness, espoused in A Theory of Justice, loses its central role in Rawls' later political philosophy (Langvatn, 2016). Second, by implication, consensus on the basic social structure is mixed with dissent and power struggles, which are unavoidable in a reasonable society (1997, p. 805).

Michael Walzer takes the opposite point of departure when investigating principles of distributive justice. His main concern is to find a general way of analyzing problems of the distribution of social goods, without the assumption that society may be grasped within a general frame of reference. In Spheres of Justice (1983) Walzer attempts to solve this problem by drawing up a broad set of social fields, each with a distinct mode of distribution (ibid., pp. 6ff.). Ten social spheres are sketched, among them politics, education, working life, social welfare and religion, but Walzer makes no claim to have covered the total number of social spheres. In contrast to Rawls, he does not posit an overarching set of norms for these fields; on the contrary, his point is to reveal their different ways of working and thus their different modes of distributing goods. Since people differ in their talents, inequalities in distributive outcomes within each of the spheres are inevitable. This is countered by a distinction between what Walzer terms simple and complex equality. Simple equality is illustrated by Rawls' difference principle, which according to Walzer, 'would require continual state intervention to break up or constrain incipient monopolies and to repress new forms of dominance' (1983, p. 15). To get around this problem Walzer presents his alternative concept of complex equality: if citizens excel in different spheres, inequalities within each sphere should be accepted on the condition that their gains are limited to the given sphere. In other words, complex equality rests on the avoidance of spillover effects between spheres; to give a crude example, money is not allowed to buy political power or positions. 
Walzer's main concern is distributive justice, not a theory of social institutions. He accentuates distributive problems as combinations of normative regulations, specific functioning and distributive outcomes. However, even though varying in their nature and scope, many of the social spheres he discusses in depth may be regarded as institutions. Despite their dissimilarities, spheres such as leisure, money and kinship, all of them among the ten taken up in Spheres of Justice, constitute institutions.

In the Introduction (Engelstad et al., this volume) basic modes of institutional functioning are sketched: various forms of institutional differentiation and change, the significance of interaction between institutions, their normative character and the unavoidable presence of conflict and internal power struggles. Even if Rawls and Walzer differ on all these issues, they have in common a meta-normative standpoint. Norms are applied not only to social action within institutional frameworks; they also concern the more general structure of institutions. The frame of reference in Rawls is the basic social structure, the macro level where society is conceived as a nation-state. In his vision, institutions are generally integrated, very different from a fragmented set of social fields. Rawls situates democracy within his conception of a basic social structure; although not unitary, it is kept together by an overlapping consensus. His meta-norm is the combination of the principles of liberty and difference. At the same time, his conception of rights, of citizen morality and of common principles, remain abstract if not anchored in specific institutions. Walzer, in contrast, does not raise the question of institutional compatibility; his discussion is generally context-free, focused solely on the internal functioning of separate institutional fields. His meta-norm is that of isolating institutions from each other, avoiding spill-over effects to make complex equality possible. However, in Walzer there is no discussion of what binds all these spheres together; except that 'the political community is probably the closest we can come to a world of common meanings' (1983, p. 28).

Institutional functioning is taken up by Rawls on general terms, whereas Walzer is very specific in his descriptions. However, the specificity in Walzer is of a particular nature as he describes it mainly in terms of social transactions, without contextual specification. This makes his descriptions abstract in a different way, having more similarities with ideal-types or models, than with empirical accounts. When it comes to conflict, neither of the two denies the salience of social conflict, but conceive it differently. Even though Rawls underscores the absence of full integration in modern societies, he emphasizes the general compatibility of institutions. The type of conflict he envisages is not situated in the working of institutions; it is mainly of a general, religious or philosophical nature to be encountered by public reason (1997). Walzer, on the other hand, due to his focus on social transactions, implicitly draws up a framework for understanding how competition within institutions results in tensions between them. A crucial problem for Walzer, then, is whether it is conceivable to keep institutions sufficiently separate without mobilizing the same forces of the state that he criticizes with regard to simple equality. 


\subsection{From Political Philosophy to Sociological Analysis}

Given that the differences between Rawls and Walzer could be interpreted in terms of complementarity, it may be tempting to construct a theory combining these two strands of thought. But their basic assumptions are too different to combine them into one unitary theory. Yet, while resisting eclecticism, it still is possible to make a transition from ideal political philosophy to non-ideal sociological analysis (Valentini, 2012) by drawing out from the two approaches theoretical points of reference, in a conception with empirical emphasis on mechanisms and constellations of mechanisms, rather than holistic theory. When related to empirical reality, broad normative theories like those of Rawls and Walzer must be operationalized; and when applied to institutions, norms must be compatible with institutional specificities.

Institutions, as they are understood in the present context, constitute common frameworks regulating social behavior of individuals and organizations, as well as basic social conflict (Dahrendorf, 1959). As such they reflect viable social compromises, in some cases even consensus. Yet, even if conflicts are mitigated, they do not disappear. They take several forms, not only as conflicts over divergent interests but as normative dilemmas, as goal conflicts, and as competing interpretations of how institutions are supposed to work. Thus, institutions become arenas for the exertion of power (Mahoney \& Thelen, 2009; Introduction, this volume). Given that institutions emerge and change by processes of differentiation and innovation, they are widely divergent in their modes of functioning. Thus, the relationship between them reflects complementarity and tensions at the same time.

The prevalence of dilemmas, tensions and conflicts within institutions points to the salience of democratic deliberation and conflict resolution. But even if institutions are vastly dissimilar, the present exposition aims to specify common democratic norms that are compatible with the functioning of several different institutions in a way not drawn up by Rawls and Walzer. Rawls points out that institutions have their own life, but does not specify how democracy may be made relevant. He uses as an illustration a church and holds that "liberal principles of political justice do not require ecclesiastical governance to be democratic.” Nevertheless, "the principles of justice [...] protect the rights and liberties of their members by the constraints to which all churches and associations are subject.” (1997, p. 789). Under a different perspective, Walzer, on the other hand, resigns from normative concessions as long as diffusion does not take place between institutions.

The present chapter aims at transcending these general and somewhat vague conceptions by specifying and operationalizing central norms in both approaches, in a way that makes them applicable across a variety of institutions. This is done by reinterpreting normative principles as gradual dimensions, which may then be balanced against other, necessary institutional claims. Three concepts central in the works of Rawls and Walzer are singled out for the following investigation of institutional fields: social membership, political equality, and individual 
autonomy. These concepts are central to the authors' theories, they are robust to varieties of institutional functioning, and they closely reflect the two main aspects of democracy outlined above: the influence of citizens on decision-making shaping their own life, and their abilities for cooperation as members of society. Alternative operationalizations are of course possible; one worthy candidate would be the specification of equal opportunities by Dahl cited above; with a strong emphasis on personal autonomy (Dahl, 1989, p. 97ff.), it overlaps with the conception presented here. However, as already mentioned, it is primarily linked to the political processes in a narrow sense, and not so easily generalized to other, social institutions. The same is true of Alexander's (2006) extended conception of democracy, which, outside the political institutions, is limited to the civil sphere.

The notion of social membership is placed first among the ten spheres treated by Walzer. His perspective concretizes the basic question of who qualifies as a citizen of a given specific social formation. In an institutional context, this may be reinterpreted as the conditions of access for citizens to given social fields, and thus who is counted as a relevant participant in a given social institution. In contrast, in Rawls the question of who is a participant is not relevant. In his original conception of justice as fairness, anyone was called to take his or her position behind the veil of ignorance, and assess a desirable structure for a possible society. The absence of a problem of inclusion is true for the later theory of public reason as well.

Political equality is a main concern in Rawls but is less elaborated by Walzer, who mostly connects it to equality of opportunity. In contrast to standard discussions anchored in political institutions, here it concerns the balance of individual rights and competing legitimate concerns in the organized patterns of power and bargaining in a given social institution. If hierarchies are inevitable, as is the case in many institutions, the institutional norm of political equality invokes the legitimacy of hierarchical relations and points to the possibility of minimizing them.

Autonomy is a core element of democracy in Rawls - citizens assuming responsibility for social cooperation. Preconditions for this are common liberties and rights, without which citizens cannot act as responsible individuals. However, when applied to particular institutions, citizens encounter specific limitations and rules, with which they have to comply. In working life, to give a simple example, employees have to find a balance between their own notions of how a job should be performed and the fairness of employer prerogatives in structuring the tasks. In Walzer autonomy does not have this normative meaning; it is implied in the freedom of action within each of the social spheres.

In the following, tensions between institutional requirements and democratic norms are examined with these three criteria. They are applied to the institutional fields that constitute the main elements of the Nordic model (Engelstad et al., 2017): the economy with emphasis on working life, the welfare state with focus on health care and social security, and the media. In each case, the discussion of the democratic norms is preceded by a brief presentation of the structural preconditions for the democratic quality of institutions. These preconditions are specifications related to, 
albeit not identical with, the two principles in Rawls: (i) the universality of rights and access to social goods, connected to the principle of equality, and (ii) the conditions of participation and influence, direct or indirect, associated to the difference principle.

\subsection{An Old Story: Democratizing the Economy}

The economy is dominated by an overarching ambivalence between autonomy and hierarchy - at the most general level, between the roles of producers and consumers and the roles of managers and workers. In the role of consumers citizens are basically in an autonomous position; in the role of producers, they are placed into drastic hierarchical systems. The relationship between management and employees is less clear-cut: employees are subordinate to management prerogatives while at the same time enjoying political autonomy as citizens.

When prospective democratic elements in the economy are discussed, old notions of 'economic democracy' inevitably come up. This is not so much a concept as a generic term to cover the expansion of political democracy into the economy (see also Teigen, this volume). It has been given several meanings, most prominently (i) state ownership of the means of production, (ii) political agency represented in decision-making bodies of enterprises and (iii) employees electing management/CEOs. All these have been tried out in practice, and none has survived in its original form. State ownership was the dominant form of ownership in Communist societies, and still is so in, for example, China, but is not a necessary condition for democracy. Some democratic countries have a large amount of public ownership in central parts of the economy, of which Norway is the most prominent example (St. Meld. 27 [2013-2014]), something that does not preclude private ownership as prevailing, given that many state-owned enterprises are run on a commercial basis. Political representation within decision-making bodies has been tried out in many versions. Two examples are the 'socialization' of commercial banks in Norway in the late 1970s and the Swedish Wage Earner Funds of the 1980s, transferring parts of the profits to public investment funds. Both were given up after a relatively short time (Engelstad, 2015). In part this had to do with problems related to the transgression of property rights and in part to goal conflicts between economic and political considerations. The election of management/CEO by workers was prominent in the 1970s and 1980s in the former Yugoslavia and Israeli kibbutzim, but at present it hardly plays a significant role. Exceptions are found in fully worker-owned enterprises, which constitute a small minority in some Westerns countries (e.g. in Emilia Romagna in Italy, with 6\% of the labour force [Rinehart, 2009]).

These mainly unsuccessful attempts at introducing democratic elements into the economy should not overshadow other aspects of democracy relevant to the economic sphere in any modern economy and their direct or indirect relationship to democratic governance - to citizen rights and autonomy within basically hierarchical work organizations. 


\subsection{Normative Preconditions of the Modern Economy}

Modern economies have at least four basic normative traits with a clear connection to democracy. These are ideal preconditions, never found in pure form, but nevertheless constitute necessary elements for the functioning of the economy: (i) property rights; (ii) freedom of contract; (iii) well-functioning markets for goods and services, including labour markets; and (iv) economic regulations and macro policies.

Property rights entail the right to freely dispose objects in the possession of the individual, whether acquired via work, gifts or inheritance (Carruthers \& Ariovic, 2003). For individual citizens in a society with a widely developed division of labour, property rights are a precondition for a basic feeling of security and stability in everyday life and constitute a precondition for the development of people's life careers. Property rights are essential to the functioning of any economy based on exchange and the division of labour. Marxist assumptions that property rights wither away if enterprises become collective property have shown themselves to be unrealistic. Any enterprise, whether privately or publicly owned, must sort out which objects are under its own legitimate control and which are under the responsibility of other actors (Fligstein, 2002). However, property rights are not unconditional; they are defined, limited and guaranteed by political decisions. Hence, their extension varies between societies and over time (Engelstad, 2015).

Freedom of contract denotes the individual right to enter into binding transactions with other parties, including the ability to annul agreements. As a general feature, freedom of contract is limited to modern, capitalist economies and is even a relatively recent element within capitalism. In parallel to property rights, the freedom of contract is not unlimited but rather politically regulated (Trebilcock, 1993). As a precondition for personal autonomy and liberty, the individual is accorded the right to assess risks and take responsibility for his or her own dispositions. Furthermore, $\mathrm{s} /$ he is free to enter into cooperation with any other actor, be it as a partner in some sort of joint venture or as an employee subordinate to the plans and disposition of other actors; freedom is retained by the possibility to annul the relationship upon a set of given conditions.

Without well-functioning markets, any modern economy will get into serious difficulties even if the idea of perfect markets, cherished by economists, is an illusion (Fligstein, 2002). Well-functioning markets allow the choice between alternative goods, and more generally between alternative structures of opportunities, constitute the prime arenas of development in economies depending on the division of labour. As actors in a market, consumers have the opportunity to make rational choices between goods as well as types of goods, which opens up for choices of life styles and - at least partly - identities (Aakvaag, this volume). The most significant element of markets in pure form, however, is that they do not discriminate between buyers and sellers; what counts is solely the supply and demand they represent. In this respect, the ideal of a perfect market acquires a normative character. 
In labour markets the goods traded have a double character; labour power is simultaneously a commodity and a part of the human person. Thus the market process implies an agreed renouncement of the freedom citizens otherwise would exercise. How is it possible to uphold human freedom under such conditions, was the question raised by the young Marx ([1844] 1986). One reply might be the ‘decommodification' of labour power (cf. Esping-Andersen, 1990) by counteracting market functioning, as was common in $19^{\text {th }}$-century paternalistic capitalism. This, however, corroborates the subordinate status of the worker. An alternative is strengthening the bargaining position of workers in the labour market by developing individual resources or building collective action. Thereby the prospective equality of market relations is utilized.

Economic regulation and macro policies reflect the fact that the economy consists of enterprises that are necessarily particularistic. Firms have specific targets and criteria of success, in contrast to politics, which has the regulation of society as a whole as its main goal. Thus, markets must be regulated to be functional, while at the same time fiscal policies create the basis for the public sector. Policies of taxation and redistribution compensate for gross inequalities created in the labour market. Freedom of contract, property rights and market functioning are also dependent on political governance. Legislation regulates the conditions of work contracts, for example, in the Scandinavian countries by the regulation of work environments. The extension of property rights must be specified and are likewise regulated by the state as concerns, for example, taxation, the legislation of inheritance and the structuring of joint-stock enterprises.

These elements are not in themselves democratic, but their ideally universalist character constitutes a precondition for democracy in modern societies. Economic differentiation entails varieties of jobs and increased freedom of choice in combination with reciprocal dependency and thus the potential feeling of solidarity, as pointed out early on by Émile Durkheim ([1893] 1997; Aakvaag, this volume). These are potential supports for democracy. Democracy, however, cannot rely solely on structural traits in the economy. It is dependent on a well-functioning state able to formulate and guarantee these elements as rights while at the same time instituting corrections to the tendency to undermine their universalist functioning.

On the other hand, enterprises are organizations and, by implication, are constituted as hierarchical systems of power. The economic division of labour is simultaneously a division of power between a minority of owners, shareholders and managers and the broad majority of employees. Power inequalities are unavoidable if organizations are to function in accordance with their goals; at the same time they are obvious sources of power abuse. A noticeable example of power abuse justified by property rights is the denial of employers to accept collective wage bargaining, found in large parts of the world, prominent also in highly developed economies. 


\subsection{Democratic Norms in the Economy}

In working life the concept of social membership relates above all to the right and possibility to work. The right to work may be interpreted literally as the right to specific forms of paid work, such as in the large programmes of employment in India. In modern societies, the notion has a more general meaning (Engelstad, 2016) primarily connected to various labour market policies. A primary aspect of the right to work is the requirement of equal access according to the qualifications for a job, emphasized by both Rawls and Walzer - in other words the absence of discrimination. It is a cherished assumption among economists that well-functioning markets make employers allergic to discrimination (Becker, 1971), but in actual practice this is far from the case. On the part of the state, membership is buttressed by ample labour market policies. A motor for job creation is Keynesian macro policies, whereas systems for vocational training and retraining make job seekers more able to find work (Nyen \& Tønder, 2015; Hagelund, this volume). At the other end of the labour market are measures for mitigating unemployment in periods of market contraction by various forms of unemployment compensation (Olberg, 2015; Svalund, 2015).

The ability to reinforce political equality rests on the institutionalized resources to counter employer prerogatives based on property rights. A core question in this connection is the definition and interpretation of property rights. The matter here is not that of abolishing property rights but acknowledging that they necessarily are politically defined. To what extent are property rights open to respecification without losing the core character of ownership rights to dispose objects? (Engelstad, 2015). If property rights are assumed to be absolute, owners and managers would have the right to deny any interference in the setting of work contracts and work conditions. This, however, is in conflict with basic civil rights, such as freedom of association and of expression (Trygstad, 2017). Hence, a balance between property rights and employee power resources is a dimension of democracy.

There is a great variety in the position of trade unions, for example in Europe: with a strong position in Scandinavia, somewhat less so in Germany and weaker in Southern Europe. Whereas trade unions are voluntary associations, they are supplemented by legislation on employee representation in bodies of deliberation and decision-making, including employee participation on the boards of directors, works councils and other fora for consultation and health and safety committees. The power of these bodies follows roughly the same pattern as that of trade unions: weak in Southern Europe, stronger in Germany and Austria and most powerful in the Nordic countries. These arrangements constitute limitations of property rights as they impede the sole right of decision-making for owners/managers (Engelstad, 2015). Even so, they mainly secure subordinate voices the right to be heard, whereas employees do not have sufficient power to overturn long-term decisions. (In addition, the power of workers hinges on the bodies of employer-worker cooperation actually being utilized [Trygstad \& Alsos, this volume].) A more recent case is legislation securing gender quotas on the boards 
of directors of listed or otherwise very large companies, introduced in Norway and about to be implemented in several other countries (Teigen, 2012; Engelstad \& Teigen, 2012). This, too, is a form of the delimitation of property rights, which does not break with the decision-making rights of owners/board members.

Various forms of wage bargaining at the national level are found in Scandinavia and foremost in Norway, where political authorities have a core role at several stages in the process. A crucial aim of state intervention is to preserve the competitive ability of the national economy on the world market. Interventions comprise consultations between the government and the employer and employee federations; professionally neutral assessments of various economic scenarios, with parts of the bargaining taking place between industry federations at the national level; and public agencies for mediation. This 'politicization' also lifts wage bargaining into the public sphere and thereby makes it a subject of democratic deliberation.

Politics protecting autonomy concerns the ability of employees to function as responsible citizens on the basis of traits specifically connected to their jobs. Most important are risks connected to health and security and accordingly the political measures of protection against accidents and work routines detrimental to health. Such measures were introduced in $19^{\text {th }}$-century capitalism by legislation regulating children's work and dangerous work. To varying degrees it has been further developed in modern societies, including legislation on psychological and socially stressful work. Work environment legislation in Scandinavian countries is very advanced in this respect. To counteract the abuse of power, some sort of countervailing power, which represents the interests of employees, is necessary within enterprises.

The points above open up for a general assessment of autonomy in working life. In the ideal version, citizens in a liberal society choose their education and thereby to a large extent choose between prospective employers. A well-functioning labour market allows the opportunity to choose between jobs and, by implication, also between organizational regimes. Given that a citizen freely chooses a job, the next question is the degree of arbitrariness in management. As long as the arbitrariness is negligible, the element of power is legitimate; if so the worker has no reason to wish it otherwise or possibly has the opportunity to suggest alternative ways of organizing the work process. To the degree that these conditions are met, the worker is autonomous in a Kantian sense; s/he follows a law that s/he freely has given her/himself (Svalund, 2003; Engelstad et al., 2003).

\subsection{Welfare State Institutions in Democracy}

The basic task of the welfare state is the inclusion of citizens in regular participation in society. The welfare state is composed of several basic institutions; here the discussion is mostly limited to institutions for health care and social security. Welfare state measures in these fields aim at maintaining or restoring - as far as practically 
possible - the ability of citizens to act as free and productive individuals. This is obtained by public agencies distributing rights-based provisions. An underlying norm of the welfare state is that of social solidarity, which takes two forms. In addition to meeting immediate needs in the population, it serves as an insurance system for those who are not needy at present but may be so in the future. For welfare states to meet the differing needs in the population, provisions generally take a redistributive character: less affluent citizens receive more and the well to do less than what they have paid as an 'insurance premium'.

A contrasting case to the welfare state is that of charity, which rests on inequality. Even if the recipient is 'worthy' of assistance, when the benefactor allocates help to the recipient, a basic subordination is confirmed as long as the recipient has no rights in the relation. The aim is short-term relief, not the maintenance or restoration of individual responsibility for his or her life. An intermediate case between charity and mature welfare state arrangements is the set of large programmes for the allocation of food and work found in India. In that case, the benefactor is the state, so in this sense political equality is untouched. Simultaneously the programmes have traits of charity as they function as poverty alleviation with little potential to bring recipients out of poverty (Engelstad, 2016).

Even though modern democracies have one form of welfare state or another (Esping-Andersen, 1990), it is in no way given that the existence of broad sets of welfare provisions is a sign of democracy. The legitimacy effects of welfare allowances are not restricted to democracies. The Bismarckian welfare system of the late $19^{\text {th }}$ century, which was very advanced for its time, reflected exactly that. Citizens were accorded a broad welfare system in exchange for the acceptance of a pseudo-democratic political system. Many of today's authoritarian regimes offer similar pictures. Hence, the link between the welfare state and democracy hinges on the political character of the organization of welfare provisions.

Their institutional character does not preclude conflicts underlying democratic welfare state arrangements. One salient conflict is that between social solidarity on one hand and citizens' responsibility for their own lives on the other. If a crucial element in democracy is the propensity of citizens to cooperate, as Rawls assumed, citizens' common consideration for the welfare of others follows as a logical consequence. Alternatively, autonomy as a democratic ideal also rests on the ability and readiness of citizens to take responsibility for their own lives. At the micro level, this is concretized in the relationship between professionalized help and care and the active participation of clients and 'users'.

This is reflected in the power relations between the roles of professionals and clients. In democratic societies their relationship is supposed not to be a between patron and client but between a principal and agent, such that the recipient is in the superior position as principal (Petersen, 1993). Nevertheless the agent (doctor, nurse, social worker) remains powerful due to her/his competence. Tensions in this ambiguous relationship may be denied by both parties; by the agent taking over and 
acting as a patron or by the user acting as a subordinate client repudiating his/her own autonomy and responsibility.

A welfare state is democratic to the extent that it is inclusive and transparent. If so, at least four institutional preconditions are important: (i) The welfare state is universal in the sense that all citizens have access to welfare provisions according to needs and other qualifications that are open to all. (ii) The welfare state is funded by the taxation of citizens. Thereby citizens have a common ownership of the welfare state system. They have a right to welfare provisions because they are funded by them and not procured by a benevolent donator. (iii) The public welfare system is the object of public policy formation. As voters, citizens have a say in how it is to be run. This also means openness to redistributive measures, which at the same time are open to public debate. (iv) The welfare state agencies are manned by professional staff; thereby the quality of provisions, along with equality among users, is maximized. At the same time the necessary use of discretion is covered by codes of professional ethics.

The significance of these points obviously varies between democratic societies. As outlined in Esping-Andersen's (1990) taxonomy of welfare state regimes, one crucial dimension is the mix of private and public elements, varying from a minimal version of public commitment in the liberal type to the maximal type found in the Nordic countries. Yet, combination is the rule; a welfare regime solely based on public provisions is not found anywhere and would probably be tyrannical rather than democratic. Within the framework of these structural preconditions, the underlying normative elements of the democratic welfare state - social membership, political equality and autonomy - are played out.

Social membership implies the possibility of all citizens to fill an acceptable position in a complex society. There is a clear parallel here to T.H. Marshall's ([1950] 1964) classical conception of social rights and social provisions. To the degree that these provisions are universal and accessible to everyone, they also function as a source of social integration. These are related not only to individual welfare but have also a separate democratic dimension. A first precondition is elementary education, yielding the ability to understand and interpret the social and political structures and processes necessary for democratic participation. Participation, moreover, presupposes that citizens are not enmeshed in surviving from one day to the next but rather have a guarantee of a minimal income. Welfare state provisions are also shading into measures connected to working life. Health and security measures within enterprises have already been mentioned. Other aspects of the interplay between working life and the welfare state are unemployment benefits and retraining and support to find jobs in cases of unemployment, sickness pay and arrangements of parental leave.

In addition to citizens as recipients of welfare state provisions, political equality relates to individuals as bearers of social rights as a part of their citizenship. Modern welfare systems are large organizational and bureaucratic complexes. Political 
equality implies an equal ability to understand and handle and make use of these organizations. One precondition is the willingness of welfare bureaucracies to make information about their services accessible to citizens, both those who are needy and those who may become so in the future. Of similar importance is the design of the organizations themselves, the degree to which they are accessible to ordinary citizens and their ability to handle grievances. In this respect, the rationalization of bureaucratic routines is a crucial contribution to democracy.

This has two additional implications. One is that all citizens have access to the agencies of the welfare state, including hospitals, nursing homes, schools and kindergartens. Within this framework they are supposed to receive treatment of the same quality, such as without serious difference of quality in medical treatment in public and private hospitals. This does not preclude the existence of private agencies offering specialized services to those who are able to pay for them. The core is equality related to what Rawls $(1971,1993)$ termed primary goods in contrast to non-essential or 'luxury' goods, even if the dividing line between these two is always open to negotiation and power struggles.

Autonomy relates to an individual's responsibility for her or his own life as well as their ability to see how one's own choices affect the welfare freedom of others. This is dependent on the individual's understanding of and willingness to assume this responsibility. But it also relates to the functioning of the welfare system and the degree to which it is constructed to incite the participation of recipients in shaping and forming the services. Dilemmas connected to principal-agent relationships have already been mentioned. One important specification is the amount and types of information given and the way that professionals invite recipients to take part in decisions with wide consequences for their welfare while at the same time not abdicating from their responsibility as professionals.

An additional aspect of autonomy concerns the relationship between the individual recipient and the allocation of additional responsibility to the family or to the state. Variation in conceptions of individual autonomy, and the relationship of individuals to the state, is another crucial element in Esping-Andersen's typology of modern welfare states. In liberal welfare states, the state has a restricted role to play; the production of welfare services is basically located in the private, marketbased sectors, and funding takes place via the private insurance sector. The state takes on the responsibility for only the most needy. In the conservative welfare states of Continental Europe, the state has a somewhat more active role, and funding is not privatized in the same way. In line with the dominant 'subsidiarity principle', families, occupational groups and local communities have a prime responsibility for mitigating social needs. In the Scandinavian welfare state, on the contrary, the goal is rather that of minimizing individuals' dependency on support from the family; in some respects it has the character of a state-supported individualism (Berggren \& Trägårdh, 2009). Moreover, the form of the welfare state has repercussions in regard to democratic participation. Comparative studies indicate that 'due to the integrative 
nature of the welfare policies', citizens are more likely to participate in elections 'in countries where the focus on working-age adults and families is greater' (Shore, 2014, p. 56; see also Busemeyer \& Goerres, 2014).

In parallel, in mature welfare states a precarious balance is coming to the surface, stemming from possible hyper-development. Presently in the Scandinavian countries welfare state benefits are changing from general allowances to comprehensive plans for reintegration, specifically targeted to each individual (Hagelund, this volume). Here a possible conflict between social integration and individual autonomy is coming to the fore. The amount of room left for personal responsibility may then be an open question. In this sense, the welfare state may materialize as a benign but authoritarian shepherd state, as previously feared by Tocqueville (after Dahl, 2001, p. 133) and, more recently, by Michel Foucault (1982-1983).

\subsection{Democracy in the Media Institution}

Systems of information, shaped by ruling groups, have always been a precondition for keeping together societies larger than local communities (Mann, 1986). In contrast, modern societies are, as famously formulated by Benedict Anderson (1983), 'imagined communities'. In modern, complex societies the media are institutionalized as a main source of the communal imagination by their diffusion to the general public. Their institutional character and practical separation from ruling groups are not sufficient conditions for the media being democratic. In large parts of the world political censorship, directly or indirectly, plays a key role in the production and diffusion of information. To be democratic, the media must have freedom of information and of expression as their normative bases (NOU 1999:27). If not, citizens are unable to make informed decisions about central social concerns and thus participate in democratic decision-making.

In democratic societies the media are exposed to two basic dilemmas. First, they are supposed to take an idealistic, liberal stance by bringing forth information for discussion among citizens about all kinds of social prospects and problems. Inclusive social deliberation presupposes that media reach out to a large number of readers or listeners. The other side of the coin is that most media are private enterprises with a commercial component, and they are expected to bring profit to their shareholders (Habermas, 1989). When reaching out to a large audience is not only a democratic but also a commercial requirement, it also unduly invites selection from and trivialization of the news panorama based on public appeal (Schudson, 2003).

The public sphere is a field of competition between social groups representing diverse interests. Within the confines of consensual 'rules of the game' (Habermas, 2009), political conflict is the rule. This leads up to the second dilemma - that of the partisan aspects in the presentation of information and news - explicitly linked to political groups or implicitly by ideological leaning. That there is no single correct way of presenting information does not deny the salience of factual statements in 
any informative message; facts are a necessary but insufficient condition for credible descriptions of a given issue (Kohring \& Matthes, 2007). A fact is a true statement about an object in the world; it may be 'objective' in a strong sense, but, if so, it is disconnected from significant contexts. To be socially meaningful, facts are selected and situated within a recognizable narrative or a chain of argumentation.

If there is no frame of reference which is the only relevant one to the description of a given issue, the public must balance different facts and interpretations against each other. In this process, truth becomes the object of political debate and ideological struggle. A challenge to democracy, then, is to procure the best possible framework and material for truthful deliberation while at the same time accepting the existence of a plurality of descriptions of the world.

At the structural level, four points are particularly relevant for the media institution to be democratic. In various ways they are connected to the basic norms of freedom of information and expression. (i) Autonomy and independence: the media shall be free to give the public access to 'all the news that's fit to print'. To live up to this expectation, the media have to defend their autonomy on two fronts. On one hand, in relationship to owners and shareholders, the right of shareholders to claim profits on their investments does not justify their possible influence on the content side of the media. On the other hand, in relationship to the state, the media have to defend their autonomy against possible state censorship. To counter these pressures, in Norway the autonomy of editors is laid down in legislation (Engelstad et al., 2017). (ii) Media pluralism, in contrast to media monopoly: ideological variation among the media serves as a bulwark against political co-optation and control of information flow (Habermas, 2009). Only if the public can chose between channels of information, reflecting the distribution of communicative power, can the media as a whole reflect the existing diversity of social and ideological voices (Karppinen, 2013). (iii) Independence of the media gives special significance to the institutionalization of professional ethics. Internal justice is directed both at guarding the credibility of information as well as considerations for privacy. If so, by implication the media create bodies that initiate debate about their social role along with treating grievances from the public on breaches of privacy or other concerns. The form of such bodies varies, but they are present in all the Nordic countries (Engelstad et al., 2017, p. 57). At the same time, professional norms are the object of conflict, both within and between professions (Engelstad, 2017). (iv) Media policy: even in highly liberal societies, such as the United States (Benson, 2009), media policy is a precondition for democracy. Basic media policies are about definitions of freedom of expression and its limits and securing media pluralism. Moreover, they involve infrastructure such as facilities for distribution as well as the regulation of competition among the media. In the Nordic region media policies are more wide-ranging; they include great investments in public service broadcasting, both concerning public ownership and the licensing of privately owned media. In parallel, a broad system of media subvention aims primarily at diversity in the production of news and opinion formation (Syvertsen, Enli, Mjøs, \& Moe, 2014; Engelstad et al., 2017). 
Varieties of media policies have been analyzed in depth by Hallin and Mancini (2004), who distinguished different media regimes on the basis of four criteria: the early development and broad diffusion of mass media; independence from political groups; professionalization and self-regulation; and state intervention aiming to protect freedom of the press. Scoring high on all four variables, the Nordic societies come out as typical examples of a democratic corporatist regime. Referring to Hallin and Mancini and Esping-Andersen (1990), Syvertsen et al. (2014, p. 20) even point out a homology between the Nordic media structure and the welfare state. In contrast, due to stronger market orientation and less comprehensive media policies, the United States, the UK, Ireland and Canada are characterized as liberal media regimes, notwithstanding strong traditions in regard to public service broadcasting in Great Britain (Hallin \& Mancini, 2004).

Within the short span of two decades, the media landscape has been drastically changed by the explosive growth of the internet and the advent of social media. The transformation of the medium of the press from newspaper to Internet, or more precisely, the combined media of paper and net, has implications for the mode of argumentation and presentation of news as reading on the net presupposes shorter and more pointed articles. Journalists are following social media and picking up news to be used in the net versions or on paper. Thereby the content landscape, the pool from which published news is drawn, is in flux; if so, the semi-private sphere of the internet increasingly defines what is relevant news; as the saying goes, in this collaboration everyone is their own editor (Bruns, 2005). If this process is mostly played out on the local level, the globalization of the internet has opened up for powerful international news distributors tailoring and thereby individualizing news consumption with the result that common arenas for deliberation are fragmented. In this process of transformation the general authority of the editorial function is shrinking, and traditional business models collapse. In parallel, digitalization and globalization in the media field affect the extension of media policies as they limit the possibilities of the state to secure pluralism, quality and identity by active media policies (NOU 2017:7). The repercussions on political democracy are ambiguous. Some of these changes entail extensions of democracy due to increased opportunities for citizens to set the agenda by influencing definitions of what is relevant news. Others point to deterioration - not because elaborate political argumentation is necessarily squeezed out but because fragmentation makes it reach a smaller portion of citizens.

As the media institution as an arena of conflict has taken new forms, the criteria for democratic participation - social membership, political equality and autonomy change in content and become even more relevant. The media foster social membership by being accessible, such that prospective users are not hindered by social, economic or physical barriers to relevant information from the media. Democratically relevant information of a type that citizens actually need to orient themselves in society must be delivered by the media and formulated in ways that are understandable to the public. The accessibility of democratically relevant information hinges not only on 
the media but also on their sources, both private and public. Counteracting closed circuits of communication is a precondition for the contribution of the media to transparency in society. Organizations of all kinds, and not least public entities, have an inherent tendency to withhold information about their dispositions to the public. To counter this tendency, general access to public documents is legislated in virtually all modern societies (www.Right2INFO.org), albeit with varying force. From 2004, the Norwegian constitution even has a clause prescribing the state to arrange for information necessary for an enlightened debate (NOU 2011:12).

Political equality concerns the ability of citizens to participate in public discourse on an equal footing. The basic precondition is freedom of expression in two aspects: on one hand the freedom of the media to bring forth information and on the other the liberty of citizens to express their opinions and desires. Freedom of expression goes hand in hand with the right of the individual to search for information in her or his own right (NOU 1999:27) in order to formulate statements directed to the public. Politically, the freedom of expression is not unlimited (Kierulf \& Rønning, 2012) and can hardly be so. Institutionally, the media have an editorial authority to select, process and present their information. If not, the flow of information would take on a chaotic nature. This delegation, however, raises strong requirements in regard to the professional ethic of editors and journalists, who nevertheless are met with low trust in the public (Moe, Thorbjørnsrud, \& Fladmoe, 2017).

The advent of social media has led to a new situation concerning political equality. The opening up of the flow of information has contributed to a significant growth of political equality. Segaard (2017) points out the mobilizing effect of social media on the interaction between the traditional communication of politicians and voters. Moreover, social media promote political mobilization among citizens and potentially their influence on political decisions (Steen-Johnsen \& Enjolras, 2017). At the same time, the social media indirectly bring challenges to the freedom of expression, not in a legal but in a social sense. While the internet has opened up for a plurality of voices, it has also opened up for the distribution of fake news and unfounded rumours along with hateful interventions, with the consequence of scaring away prospective participants from internet debates (Nadim \& Fladmoe, 2017). The implication is a decline in the freedom of expression.

The basis for individual autonomy concerns the possibility of citizens to make well-informed judgements about important social issues. In addition to media pluralism - that is, citizens' actual freedom to choose between media of different orientation (Karppinen, 2013) - autonomy depends on the quality and reliability of the information retrieved. In the absence of definite interpretations of political issues, the credibility of basic documentation becomes essential for well-informed judgements. At an overarching level, to take part in deliberation in a serious sense, citizens of a democracy must be able to grasp the reasons why different opinions are formed, thereby making ambiguities visible and interpretive dilemmas understandable. 


\subsection{Generalizing Institutional Norms and Conflicts}

The main social institutions are heterogeneous; they comprise, and are even built around, deep social dilemmas or conflicts that cannot be solved once and for all but rather necessitate compromises. Thus, if social struggles over compromises and reformulations of compromises are unavoidable, they are by nature changeable. For this reason democratic deliberation becomes crucial. The main institutional conflicts discussed in this chapter are summarized in Table 2.1. If these conflicts are of a diverse nature, given that they are played out in institutional spheres with different structural characteristics, they also show common traits and institutional complementarities.

Table 2.1. Basic institutional conflicts in the economy, welfare state and media

\begin{tabular}{lll}
\hline & Macro structure & Micro behaviour \\
\hline Economy & $\begin{array}{l}\text { Coordination/market } \\
\text { functioning }\end{array}$ & Hierarchy/autonomy \\
Welfare state & $\begin{array}{l}\text { Solidarity/individual } \\
\text { insurance }\end{array}$ & $\begin{array}{l}\text { Professionalism/personal } \\
\text { responsibility }\end{array}$ \\
Media & $\begin{array}{l}\text { Public enlightenment/ } \\
\text { commercial viability }\end{array}$ & $\begin{array}{l}\text { Credible descriptions/ } \\
\text { ideological selection of facts }\end{array}$ \\
\hline
\end{tabular}

At the macrolevel, a common themeacross institutional fields is the variety of tensions between social regulations and individual action. In modern democracies, both tendencies are necessarily present. They reflect the salience of stable environments for citizens to make reasonable choices, while at the same time the stability of these structures is jeopardized both by intentional attempts to change the rules and the aggregate, more or less unintended, effects of a myriad of individual choices. This pattern is most commonly pointed out in regard to the economy; today perhaps the most pressing case is that of the media in the present period of transformation. At the micro level, the common element is the presence of power relations, concretized as hierarchical prerogatives, as professional competency and dependence, or as cultural hegemony and power of definition. It is no bold assumption that similar kinds of conflicts can be found in other institutional fields as well.

Democratic norms across institutional fields may equally be subsumed under a set of common terms. In a general sense, the criterion of social membership concerns various forms of exclusion from basic social institutions. In working life this refers to the citizens' general access to decent positions in the labour market. In the welfare state, social membership is expressed by the degree of access to health care and social services. In the media sector, social membership is a function of 
access to socially relevant information via the media or otherwise. All of these cases represent different types and degrees of dualization (Thelen, 2014). The degree to which dualization is a consequence of institutional preconditions may serve as a measure of the quality of democracy.

The basic meaning of political equality refers to the quality of social hierarchies in which citizens are involved. If social hierarchies are unavoidable, a democratic requirement is that the ordinary citizens involved in them are not oppressed by the powers of their superiors. In this sense democracy implies a minimization of power differentials (Shapiro, 1999). In working life this may mean the presence of trade unions or legislated arrangements of participation in decision-making in the enterprise. In the welfare state this is based in the roles, rights and amount of information on patients, clients or users vis-à-vis their professional counterparts in deciding on the treatment they receive. In the media field the main matter is the possibility of the citizen to be heard, either directly or indirectly, through spokespersons. Thus, pluralism in the diffusion of factual information and evaluative interpretation contributes to the mitigation of information hierarchies. All three examples may be subsumed under the concept of countervailing powers. Countervailing powers do not abolish hierarchies but rather modify them, and in this sense they become measurements of the quality of democracy.

Autonomy refers to the ability to act responsibly within the framework of legitimate regulations necessary for the operation of a given institution. Whereas both membership and political equality are the results of how institutions are designed, autonomy also includes active choice on the part of the individual citizen in addition to institutional structure. In working life this relates to the choices of education, occupation and jobs made by the individual in combination with the degree to which the individual actually has the possibility to make a choice, such as on which job to take. In the realm of the welfare state the question concerns the balance between dependence on helping professions and the responsibility of the individual for his or her own welfare. In addition to individual motivation this is also dependent upon the transparency of the welfare system, the possibility for its users to understand how it works. In the media field, the participation of the individual in deliberative processes is dependent on his/her readiness to obtain relevant information, but equally important is the quality of the information accessible to the public and its openness to dilemmas and differing interpretations. Common to these examples is the notion of freedom, understood as the freedom of individuals shaped by the requirement of equal freedom for others. In the present cases, the freedom of the individual is balanced by the working rules of institutions operated by the professions of managers, health personnel and editors. Accordingly, these actors bear decisive responsibility for the citizens' conditions of freedom. 


\subsection{A Brief Conclusion}

At the beginning of this chapter a reformulation of Carole Pateman's (1970) concept of participatory democracy was indicated. Whereas Pateman's main argument is directed to employee participation in working life, the present discussion reaches beyond that to a broader set of social institutions. It may be argued that her insistence on working life has lost its force since Pateman wrote about it; in the meantime different kinds of institutions for worker influence have been introduced in most European countries and particularly in the Nordic countries (p. 32f. above). The main problem does not lie here, however, but in Pateman's lack of attention to the distinctive features of institutions. In the case of working life neither the salient position of property rights nor the complexities of decision-making in politics and the economy is discussed. Without dismissing Pateman's emphasis on democratic participation, this chapter specifies it on a more realistic basis. The democratic potential in several different institutions has been investigated as concerns both the general structure of each institution and the realization of their democratic potential without destroying the basic mode of operation.

Substantively, the point of departure of this chapter is the quality of democracy and its measurement - whether it makes sense to draw up a conceptual continuity between democratic norms and their specification within given restrictions in institutional frameworks. The discussion opens up for several conclusions. (i) It makes sense, indeed, to develop democratic criteria for the design of institutions. They have specific forms in each institution but may be summarized under some general headings. (a) Power relations function as conditions for micro relations in institutions. Democratic aspects are related to the desirability of justifying and minimizing power differentials. (b) Tensions between social regulations and individual initiatives and action must constantly be handled in institutions. This opens up for constant negotiations over individuals' responsibility for their own prospects and their own life and the legitimate claims on social solidarity and support. (ii) These democratic preconditions in turn serve as frameworks for the application of norms of membership, political equality and autonomy outside the political realm. Total realization of these ideals is implausible because they must be modified in the encounter with institutional rules. However, the same is true for the political institutions; they never avoid serious imperfections within their design. Despite their only partial realization, the criteria of democratic quality may be operationalized as gradient scales for the evaluation of the design and structure of institutions - that is, to what degree a society contributes to minimizing dualization, strengthening countervailing powers and maximizing citizens' freedom.

Next, how useful are these concepts for measurements of democratic quality? Important here is operationalization, whether norms are translatable into the practical dimension. But elaborating indicators that are immediately applicable is not the ambition of the present discussion. Nevertheless, it illustrates a great potential for improvement in democratic functioning. Moreover, the brief descriptions of 
each institutional field have demonstrated that more detailed operationalization is possible in the three fields investigated and that it is no daring assumption that they are appropriate for other institutions as well.

What constitutes a democratic society, beyond a democratic state, was signalled as the main topic of this chapter. Yet, what makes up a democratic state varies greatly between countries; the political science literature is filled to the brim with comparisons of electoral systems and other relevant features of political institutions. It is not the aim of the chapter to judge the advantages or disadvantages of the various political arrangements. At the same time, what constitutes a democratic society is dependent on the design and functioning of its political institutions. The empirical references in the present discussion relate to the functioning of democracy in the Nordic countries; hence, the specifications of democratic norms are related to the Nordic model. Even so, they have a certain transfer value. This may be illustrated by a simple example. In the Nordic countries trade unions enjoy a very strong position and influence a broad set of political issues. This is a democratic advantage. As such, this structure is hardly transferable to other societies, but the norms of membership, political equality and autonomy are still applicable, even if the institutional structure is different. Even more so, the notion of countervailing power remains relevant as a sensitizing concept, even when it is differently operationalized.

The further question of the empirical effects of democratic norms lies outside the present discussion. Suffice it to say that systematically adding the conceptions of democracy to the non-political parts of society brings forth considerations, norms and expectations that, if realized, are liable to increase the quality of citizens' lives. In itself this represents a considerable gain in democracy. If and why the quality of political democracy in the more limited sense is also affected must be a topic for further research. Some indications, however, may be found in the contributions to this volume.

\section{References}

Alexander, J. (2006). The Civil Sphere. Oxford: Oxford University Press.

Anderson, B. (1983). Imagined Communities. London: Verso.

Becker, G. (1971). The Economics of Discrimination. Chicago: Chicago University Press.

Benson, R. (2009). Shaping the Public Sphere: Habermas and Beyond. American Sociologist, 40, 175-197.

Bruns, A. (2005). Gatewatching : collaborative online news production. New York: P. Lang.

Busemeyer, M.R. \& Goerres, A. (2014). Varieties of Capitalism, Education and Inequalities in Political Participation. In S., Kumlin \& I. Stadelmann-Steffen, (Eds.), How Welfare States Shape the

Democratic Public (pp. 63-89). Cheltenham: Edward Elgar.

Carruthers, B. \& Ariovic, L. (2003). The Sociology of Property Rights. Annual Review of Sociology, 30, 23-46.

Dahl, R. (1989). Democracy and Its Critics. New Haven: Yale University Press.

Dahl, R. (2001). How Democratic is the American Constitution? New Haven: Yale University Press. 
Dahrendorf, R. (1959). Class and Class Conflict in Industrial Society. Palo Alto: Stanford University Press.

Diamond, L. (2016). In Search of Democracy. London: Routledge.

Diamond, L., Green, E.C., \& Gallie, W. (2016). Measuring Democracy. In L. Diamond, In Search of Democracy (pp. 46-75). London: Routledge.

Durkheim, E. ([1893] 1997). The Division of Labour in Society. New York: The Free Press.

Enjolras, B. \& Steen-Johnsen, K. (2017). The Digital Transformation of the Political Public Sphere: A Sociological Perspective. In F. Engelstad, H. Larsen, J. Rogstad, \& K. Steen-Johnsen (Eds.), Institutional Change in the Public Sphere. Views on the Nordic Model. London, Warsaw: De Gruyter Open.

Engelstad, F. (2015). Property Rights, Governance and Power Balances. In F. Engelstad \& A. Hagelund, (Eds.), Cooperation and Conflict the Nordic Way. Work, Welfare and Institutional Change in Scandinavia. London, Warsaw: De Gruyter Open.

Engelstad, F. (2016). Welfare State - India and Scandinavia: Social Rights, Decommodification, Democracy. In O. Thörnquist \& J. Harriss (Eds.), Reinventing Social Democratic Development. Copenhagen: Nias Press.

Engelstad, F. (2017). Strategic Communication and Institutional Change. In F. Engelstad, H. Larsen, J. Rogstad, \& K. Steen-Johnsen (Eds.), Institutional Change in the Public Sphere. Views on the Nordic Model. London, Warsaw: De Gruyter Open.

Engelstad, F., Svalund, J., Hagen, I.M., \& Storvik, Aa. E. (2003). Makt og demokrati i arbeidslivet. Oslo: Gyldendal Akademisk.

Engelstad, F. \& Teigen, M. (Eds.) (2012). Firms, Boards and Gender Quotas: Comparative Perspectives. Comparative Social Research, Volume 29. Bingley: Emerald.

Engelstad, F., Larsen, H., \& Rogstad, J. (2017). The Public Sphere in the Nordic Model. In F. Engelstad, H. Larsen, J. Rogstad, \& K. Steen-Johnsen (Eds.), Institutional Change in the Public Sphere. Views on the Nordic Model. London, Warsaw: De Gruyter Open.

Esping-Andersen, G. (1990). Three Worlds of Welfare Capitalism. Princeton: Princeton University Press.

Fligstein, N. (2002). The Architecture of Markets. Princeton: Princeton University Press.

Foucault, M. (1982-1983). The Government of Self and Others: Lectures at the Collège de France, 1982-1983. New York: Palgrave Macmillan

Habermas, J. (1989 [1962]). The Structural Transformation of the Public Sphere. Cambridge: Polity. Habermas, J. (2009). Political Communication in Media Society: Does Democracy still have an Epistemic Dimension? The Impact of Normative Theory on Empirical Research. In J. Habermas, Europe. The Faltering Project. Cambridge: Polity.

Hall, P. \& Taylor, R.C.R. (1996). Political Science and the Three New Institutionalisms. Political Studies, 44, 936-957.

Hallin, D. C., \& Mancini, P. (2004). Comparing Media Systems: Three Models of Media and Politics. Cambridge: Cambridge University Press.

Karppinen, K. (2013). Rethinking Media Pluralism. New York: Fordham University Press.

Kierulf, A. \& Rønning, H. (Eds.), (2009). Freedom of Speech Abridged? Cultural, Legal and Philosophical Challenges. Gothenburg: Nordicom.

Kohring, M. \& Matthes, J. (2007). Trust in Media. Development and Validation of a Multidimensional Scale. Communication Research, 34(2), 231-252.

Langvatn, S.Aa. (2016). Legitimate, but unjust; just but illegitimate: Rawls on political legitimacy. Philosophy and Social Criticism 42(2), 132-153.

Mahoney, J., \& Thelen, K. (2009). A Theory of Gradual Institutional Change. In J. Mahoney \& K. Thelen (Eds.), Explaining Institutional Change. Cambridge. Cambridge University Press.

Mann, M. (1986). The Sources of Social Power. Cambridge: Cambridge University Press. 
Marshall. T. M. ([1950] 1964). Citizenship and Social Class. In T.M. Marshall, Class, Citizenship, and Social Development. New York: Doubleday.

Marx, K. ([1844] 1986). The Economic and Philosophic Manuscripts 1844. In J. Elster (Ed.), Karl Marx: A Reader. Cambridge: Cambridge University Press.

Moe, H., Thorbjørnsrud, K., \& Fladmoe, A. (2017). Perceptions of Journalistic Bias. Party Preference, Media Trust and Attitudes towards Immigration. In A.H. Midtbøen, K. Thorbjørnsrud, \& K. SteenJohnsen, (Eds.), Boundary Struggles, Contestations of Free Speech in the Norwegian Public Sphere. Oslo: Cappelen Damm Akademisk. DOI https://doi.org/10.23865/noasp.16

Nadim, M. \& Fladmoe, A. (2017). Hate Speech as a Social Boundary to Free Speech. In A.H. Midtbøen, K. Thorbjørnsrud, \& K. Steen-Johnsen, (Eds.), Boundary Struggles, Contestations of Free Speech in the Norwegian Public Sphere. Oslo: Cappelen Damm Akademisk. DOI https:// doi.org/10.23865/noasp.16

Nicolaisen, H., \& Trygstad, S. (2015). Preventing Dualization the Hard Way - Regulating the Norwegian Labour Market. In F. Engelstad \& A. Hagelund, (Eds.), Cooperation and Conflict the Nordic Way. Work, Welfare and Institutional Change in Scandinavia. London, Warsaw: De Gruyter Open.

North, D. (1990). Institutions, Institutional Change and Economic Performance, Cambridge: Cambridge University Press.

NOU (1999:27). Trykkefrihed bør finde Sted. Oslo: Justis- og beredskapsdepartementet.

NOU (2011:12). Ytringsfrihet og ansvar i en ny mediehverdag. Oslo: Kulturdepartementet.

NOU (2017:7). Det norske mediemangfoldet - En styrket mediepolitikk for borgerne. Oslo: Kulturdepartementet.

Nyen, T., \& Tønder, A. (2015). Cooperation and Reform in Vocational Education and Training. In F. Engelstad \& A. Hagelund, (Eds.), Cooperation and Conflict the Nordic Way. Work, Welfare and Institutional Change in Scandinavia. London, Warsaw: De Gruyter Open.

Olberg, D. (2015). Regulating the Temporary Layoff Institution - Coalitions and Drift. In F. Engelstad \& A. Hagelund, (Eds.), Cooperation and Conflict the Nordic Way. Work, Welfare and Institutional Change in Scandinavia. London, Warsaw: De Gruyter Open.

Pateman, C. (1970). Participation and Democratic Theory. Cambridge: Cambridge University Press.

Petersen, T. (1993). Recent Developments in the Economics of Organization: The Principal-Agent Relationship. Acta Sociologica 36 (3), 277-293.

Rawls, J. (1971). A Theory of Justice. Cambridge: Harvard University Press.

Rawls, J. (1993). Political Liberalism. New York: Columbia University Press.

Rawls, J. (1997). The Idea of Public Reason Revisited. The University of Chicago Law Review 64(3), $765-807$

Rawls, J. (2002). Justice as Fairness. A Restatement. Berkeley: University of California Press.

Rinehart, J. (2009). Building Resilient Sustainable Economies via the Cooperative Sector and Flexible Specialization: Lessons from the Emilia Romagna Region of Italy. Working paper: Appalachian State University.

Schudson, M. (2002). The Sociology of News. New York: Norton.

Shore, J. (2014). How Welfare States Shape Participative Patterns. In S., Kumlin \& I. StadelmannSteffen (Eds.), How Welfare States Shape the Democratic Public (pp. 41-62). Cheltenham: Edward Elgar.

St. Meld. 27 (2013-2014). Et mangfoldig og verdiskapende eierskap. Oslo: Ministry of Industry and Fisheries.

Svalund, J. (2003). Organisering, autonomi og arbeidstempo. Søkelys på arbeidsmarkedet, 20, 87-94.

Svalund, J. (2015). Cooperation and Power in Labour Adjustment Choices: A Nordic Perspective. In F. Engelstad \& A. Hagelund (Eds.), Cooperation and Conflict the Nordic Way. Work, Welfare and Institutional Change in Scandinavia. London, Warsaw: De Gruyter Open. 
Syvertsen, T., Enli, G., Mjøs, H., \& Moe, H. (2014). The Media Welfare State. Ann Arbor: University of Michigan Press.

Teigen, M. (2012). Gender Quotas on Corporate Boards: On the Diffusion of a Distinct National Policy Reform. In F. Engelstad \& M. Teigen (Eds.), Firms, Boards and Gender Quotas: Comparative Perspectives. Comparative Social Research, Volume 29 (pp. 115 - 146). Bingley: Emerald.

Teigen, M. (2015). The Making of Gender Quotas for Corporate Boards in Norway. In F. Engelstad \& A. Hagelund, (Eds.), Cooperation and Conflict the Nordic Way. Work, Welfare and Institutional Change in Scandinavia. London, Warsaw: De Gruyter Open.

Trebilcock, M.J. (1993). The Limits of Freedom of Contract. Cambridge: Harvard University Press.

Trygstad, S. (2017). Opposing Forces: On Whistleblowing in Norwegian Working Life. In F. Engelstad, H. Larsen, J. Rogstad, \& K. Steen-Johnsen (Eds.), Institutional Change in the Public Sphere. Views on the Nordic Model. London, Warsaw: De Gruyter Open.

Valentini, L. (2012). Ideal vs. Non-ideal Theory: A Conceptual Map. Philosophy Compass 7/9, 654-664.

Walzer, M. (1983). Spheres of Justice. Oxford: Blackwell. 